\title{
Ativismo coletivo e descolonização midiática: uma análise comparativa das produções audiovisuais indígenas na Austrália e no Brasil
}

Aline Frey*

\section{Resumo}

Neste artigo, eu pretendo analisar produções audiovisuais feitas por coletivos Indígenas. Na Austrália, o foco está no canal público de televisão NITV (Televisão Nacional Indígena). No Brasil, o principal projeto analisado é o VNA (Vídeo nas Aldeias). Meu objetivo é encontrar pontos de convergência/divergência entre produções coletivas Indígenas nesses dois estados-nacionais. As análises comparativas irão abordar simultaneamente conteúdos estéticos e políticos, dando especial atenção às produções que fortalecem o processo de descolonização midiática ao retratarem a vida cotidiana contemporânea dos povos Indígenas.

Palavras-chave: Cinema Indígena. Televisão Indígena. Descolonização midiática.

\footnotetext{
* Doutoranda e bolsista da Faculdade de Artes e Comunicação da Universidade de Queensland, Austrália. Mestre em Cinema pela Universidade de Otago e Pós-graduação em Artes pela Universidade Victoria de Wellington (Nova Zelândia). Psicologa pela Universidade Federal da Bahia. No Brasil, fez parte da produtora Vogal Imagem e dirigiu alguns curtas metragens e documentários premiados como A Cidade Cargueiro e Pelores. Atualmente integra a comissão organizadora da próxima edição do Festival Indígena Cine Kurumim 2017. E-mail: aline.frey@uq.edu.au
} 


\section{Collective activism and media decolonisation: a comparative analysis of indigenous audiovisual productions in Australia and Brazil}

\author{
Activismo colectivo y descolonización \\ de los medios: un análisis comparativo \\ de las producciones audiovisuales \\ indígenas en Australia y Brasil
}

\section{Abstract}

In this article, I aim to analyse audio-visual productions made by Indigenous peoples collectives. In Australia, my study focuses on the public television channel NITV (National Indigenous Television). In Brazil, the main project that I study is VNA (Video in the Villages). My main goal is to find points of convergence/divergence between Indigenous collective productions in these two national states. Comparative analysis will address both aesthetic and political contents, paying particular attention to productions that strength the process of media decolonisation when portraying Indigenous Peoples' contemporary everyday lives.

Keywords: Indigenous Cinema. Indigenous Television. Decolonizing Media.

\section{Resumen}

En este artículo, mi objetivo es analizar las producciones audiovisuales realizadas por colectivos de los pueblos Indígenas. En Australia, mi estudio se centra en el canal de la televisión pública NITV (Televisión Nacional Indígena). En Brasil, el principal proyecto que estudio es VNA (Vídeo de los Pueblos). Mi objetivo es encontrar puntos de convergencia/divergencia entre producciones colectivas Indígenas en estos dos estados nacionales. Mi análisis comparativo abordará contenidos estéticos y políticos, prestando especial atención a las producciones que fortalecen el proceso de descolonización de los medios cuando retratan la vida cotidiana contemporánea de los pueblos Indígenas.

Palabras clave: Cine Indígena. Televisión Indígena. Descolonización de los Medios. 


\section{Introdução}

Neste artigo, eu discuto o papel do cinema e da televisão Indígena como uma forma contemporânea de expressão cultural, que ao mesmo tempo permite o registro de muitas tradições Indígenas, como a transmissão de conhecimentos a partir de histórias orais, danças, músicas e pinturas. Especificamente, eu analiso as produções audiovisuais realizadas por coletivos Indígenas em dois países do hemisfério Sul, um situado na Oceania e outro na América Latina: a Austrália e o Brasil. No caso da Austrália, eu me concentro no desenvolvimento da mídia Indígena até a criação do canal público de televisão NITV (Televisão Nacional Indígena). Na ausência de um canal de televisão Indígena no Brasil, escolhi examinar o projeto VNA (Vídeo nas Aldeias), que tem uma coleção impressionante de curtas-metragens e documentários, muitos dos quais estão disponíveis online.

As minhas análises comparativas se concentram simultaneamente nas escolhas estéticas e nos conteúdos políticos das produções audiovisuais desses dois projetos em seus respectivos países. Gaunson (2013, p.763) argumenta que, ao focar apenas no conteúdo político das produções Indígenas, a maioria dos estudiosos e pesquisadores acabam excluindo-as dos debates estéticos. Consequentemente, essas produções assim como seus(as) diretores(as) são raramente situados em discussões mais amplas na esfera do cinema nacional e global. Ao dar igual atenção para ambos os aspectos, tanto formais/estéticos quanto para os significados políticos dessas produções audiovisuais, eu tenho como objetivo situar e reforçar a importância da mídia Indígena (cinema e televisão) no cenário global e também nacional (específico de cada país aqui estudado).

Os povos Indígenas no Brasil e na Austrália estão geograficamente distantes, mas ainda assim muito próximos em termos de suas lutas contemporâneas pelo direito as suas terras, assim como contra a discriminação racial/ étnica e a exclusão social. Durante a maior parte do período colonial e pós-colonial, os povos Indígenas no Brasil e na Austrália foram representados como objetos de filmes etnográficos. ${ }^{1}$ Neste sentido, os produtos audiovi- suais estudados aqui devem ser entendidos como parte dos esforços contínuos para a descolonização midiática nesses países. A tentativa de produzir histórias com/e para os povos Indígenas é hoje um movimento internacional (GINSBURG, ABU-LUGHOD AND LARKIN 2002). Com os povos Indígenas posicionados atrás das câmeras, finalmente se tornou possível para eles narrarem suas próprias histórias através da auto-representação e das parcerias autorais com realizadores não-Indígenas.

Neste novo cenário, muitos povos Indígenas têm finalmente assumido o controle da câmera invertendo a sua posição de objeto para autor (GINSBURG 1991). No entanto, é importante perguntar quais são as consequências estéticas e políticas dessa posição invertida, e se essa mudança esta explicitamente colocada nessas novas produções audiovisuais? - Para a acadêmica Indígena Americana, Michelle Raheja, a resposta é que 'sim'. Ela define o cinema Indígena como responsável por exibir uma estética específica que tem um "foco de atenção em um espaço geográfico particular, práticas culturais distintas, textos socialmente engajados, tradições espirituais, e noções de temporalidade" que conectam o passado com o presente e o futuro dos povos Indígenas (2010, p.203). Houston Wood (2008, p.1) define que "em maior ou menor grau, todos os filmes Indígenas refletem as tradições de contar histórias específicas aos povos Indígenas que estão sendo representados".

Colleen McGloin (2015, p.134) também insiste sobre as especificidades de filmes Indígenas, argumentando que podem constituir "um gênero próprio" e, a fim de chegar a uma resposta de um público determinado, "gêneros refletem esforços para organizar e hierarquizar textos e práticas culturais". McGloin defende "textos multi-genéricos" que, "para iludir categorização", são capazes de desorganizar "o arranjo dos significados e a organização do conhecimento". Neste sentido, a definição dos filmes Indígenas como parte de um gênero se baseia no argumento de que ele permanece "pouco claro" (p.135). Nesse sentido, estes filmes podem ser agrupados sob a égide do cinema Indígena por um número de razões diferentes. Uma delas é para fomentar a descolonização midiática, produzindo narrativas contemporâneas sobre 
o cotidiano dos povos Indígenas, a partir de suas próprias vozes e olhares.

Barry Barclay usa a tradicional divisão de Primeiro Cinema (referente a produção de Hollywood), Segundo Cinema (referente aos filmes de Arte europeus) e do Terceiro Cinema (referente aos filmes Latino Americanos da década de 1960, que evocavam um discurso politicamente engajado contra as formas de opressão imperialistas) para definir o cinema Indígena como Quarto Cinema. Ele argumenta que esta é uma oportunidade para "retrabalhar os valores fundamentais antigos e para dar forma a um Cinema Indígena que esta crescendo fora da ortodoxia nacional" (2003, p.11). Na verdade, esta categorização permite localizar filmes Indígenas em tensão, ao invés de se conformarem como projetos nacionalistas como acontece no Primeiro, Segundo e Terceiro Cinema. Nesse sentido, o cinema Indígena estaria em constate tensão com o projeto de cinema nacional desenvolvido por casa país.

Cinema nacional é um termo chave para a teoria e crítica de cinema, especificamente para debates sobre identidade nacional. Como explicado por Higson (1989, p.36), o termo cinema nacional é frequentemente usado para descrever filmes feitos dentro das fronteiras dos Estados-Nação. No entanto, devido ao fato deste termo ter sido utilizado em uma variedade de circunstâncias e discursos, não há nenhuma definição unanimemente aceita para ele. Na acepção do acadêmico Australiano Tom O’Regan (1996, p.45), "cinemas nacionais são ao mesmo tempo um movimento e uma produção estética, uma tecnologia crítica, um projeto cívico de Estado, uma estratégia industrial e um projeto internacional formado em resposta aos cinemas internacionais dominantes".

Nesse sentido, apesar das produções nacionais de cinema serem resultado principalmente dos subsídios públicos do Estado e da legislação fiscal de incentivos, a sua sobrevivência a longo prazo depende de sua capacidade de atrair mercados internacionais. Portanto, debates sobre cinemas nacionais necessariamente exigem uma compreensão da relação entre nacionalismo, cidadania e globalização. Neste sentido, os filmes são produtos diretos de contextos sociais, históricos, culturais e políticos de cada indústria de cinema nacional que luta para atrair, simultaneamente, audiências e mercados locais e globais.

Elsaesser (2005, p.36) afirma que o conceito de nação existe "em um campo de força de inclusão e exclusão, bem como de resistência e apropriação". Além disso, ele argumenta que os discursos de identidade nacional são constituídos através da tentativa de processos repressivos para excluir todos os tipos de diferenças, de raça a religião, na esperança de forjar uma unidade coerente e forçando um processo de "colonização interna"(p.36). É possível, então, para um termo tão abrangente como cinema nacional ser capaz de se apropriar de produções Indígenas audiovisuais, quando estes filmes não são necessariamente alinhados com a identidade cultural dos Estados nacionais específicos? Minha opinião é que o cinema Indígena pode problematizar essa unidade, apresentando diferentes identidades culturais e nações que não necessariamente reconhecem ou se identificam com um projeto de Estado-nação. Cinema Indígena pode ser parte do financiamento da política de Estado, mas ao mesmo tempo ele também pode divergir de projetos de identidade nacionais, como da promoção das línguas pós-coloniais (inglês-australiano e o português-brasileiro) ou identidades unificadas de cidadania (australianos e brasileiros) e da soberania dos estados nacionais (os países Austrália e Brasil).

Devido às razões orçamentarias, as produções do cinema Indígena têm sido até agora centrada na realização de documentários. Pearson e Knabe $(2015$, p.9) fizeram uma lista de filmes Indígenas de ficção produzidos ao redor do mundo até o ano de 2015, para demostrar que havia apenas um pouco mais de uma centena deles. Embora o número não seja impressionante, ele pode ser considerado significativo, se levarmos em conta "que os povos Indígenas estão espalhados em pequenas quantidades em todo o mundo e têm acesso raro e decididamente desigual ao financiamento, aos meios de produção, divulgação e aos acordos de distribuição" (PEARSON e KNABE, 2015, p.14). Outra questão é que a maioria dos filmes Indígenas lançados até hoje representam apenas alguns 
do extraordinário número de culturas Indígenas em todo o mundo (PEARSON e KNABE, 2015, p.37). Neste contexto, também é importante considerar a situação real da produção e exibição audiovisual. Como a acessibilidade aos cinemas é um verdadeiro desafio para os povos Indígenas vivendo em áreas remotas, outros meios de comunicação estão substituindo e influenciando as maneiras em que os filmes são feitos e exibidos. Este é exatamente o caso dos dois projetos de mídia que analiso aqui: NITV e VNA. Ambos usam a televisão e a Internet respectivamente, como principais veículos para atingirem o público geral. No entanto, isso não significa que as suas produções também não sejam exibidas em festivais internacionais e salas de cinema.

\section{A Mídia Indígena na Austrália e a criação da NITV}

O desenvolvimento da mídia Indígena na Austrália está profundamente enraizado no modelo baseado na produção de base comunitária, como uma estratégia para a autodeterminação e representação dos povos Aborígenes (RENNIE e FEATHERSTONE, 2008). Sua história remonta ao início dos anos 1980, quando os povos Indígenas estavam experimentando na produção da televisão local em comunidades como em Yuendumu (a noroeste de Alice Springs) e Pukatja (em Inglês, Ernabella, localizado ao sul da cidade do Território do Norte). Como resultado, em 1985 a comunidade Warlpiri em Yuendemu criou a primeira estação de televisão Indígena na Austrália. Antes disso, em 1977, Kerry Packer, empresário e proprietário do canal nove (em Melbourne e Sydney), propôs ao governo de Malcolm Fraser (1975-1983) um plano para expandir os negócios de televisão em toda a Austrália.

Como consequência, AUSSAT, de propriedade do governo e um dos primeiros sistemas nacionais de comunicação via satélite do mundo, foi lançado com sucesso em 1985. Este foi sem dúvida um momento de transformação na história da televisão Indígena na Austrália. A partir desse momento a transmissão de televisão e rádio se tornaram acessíveis aos povos Indígenas que vivem em comunidades remotas. No entanto, essa novidade levantou preocupações sobre os impactos que a mídia poderia ter sobre as culturas Indígenas (RENNIE 2013). O Governo Federal criou um programa chamado Programa de Serviços do Satélite (SPS) para investigar a melhor maneira de expandir a produção da mídia nacional. Também foi realizado um relatório chamado "Da Terra Silenciosa" (1984), para estudar o impacto específico do satélite em comunidades remotas.

A Associação Central de Mídia Aborígene Australiana (CAAMA) informou ao SPS "que algumas comunidades Aborígenes na Austrália Central já estavam produzindo conteúdo audiovisual" e "pediu algum sistema de transmissão Indígena local" (MEADOWS e MOLNAR 2002, p.13). Em 1987, o serviço de Broadcasting para Comunidades Aborígenes Remotas (BRACS) deu os recursos para que se tornasse possível fazer a transmissão de programas locais (RENNIE 2013). Eles estavam disponíveis para cerca de 80 comunidades remotas. Embora essas unidades locais tenham prosperado, existe a crítica de que a falta de capacitação e diálogo com as comunidades resultou na utilização de tecnologia para streaming de programas comerciais, ao invés de motivar a produção de conteúdo local (MEADOWS e MOLNAR 2002).

Ao mesmo tempo, o governo Australiano criou quatro licenças para atender as comunidades remotas. $\mathrm{O}$ chamado Serviço Remoto de Televisão Comercial (RCTS) atuou em diversas áreas do país, no Norte, Oeste, Central e Sudeste, mas o último não foi iniciado (JACKA 1992). A CAAMA ganhou a licença da região Central e, junto com outras organizações Indígenas, criou em 1988, a primeira televisão comercial Indígena do mundo: Imparja (MEADOWS 2009). O objetivo foi estabelecer uma televisão comercial que poderia trazer ao mesmo tempo informação e entretenimento para os povos Indígenas em áreas remotas (SPURGEON 1989). Para realizar os seus objetivos, na década de 1990, Imparja, juntamente com outros serviços de televisão da área, criou o CTN (Rede de Televisão Central). Imparja foi capaz de restringir anúncios (especialmente de bebidas alcoólicas), produzindo "serviços de notícias locais responsáveis perante as preocupações Aborígines" e ajudar a melhorar "a perspectiva dos não-Aborígenes em relações a comunidade Aborígene local" (O'REGAN e BATTY 1993, p.173). 
Devido às restrições financeiras, foram produzidas muito poucas horas de conteúdo local e a maior parte de sua programação era baseada na exibição de programas da mídia comercial. Em 2001, o ICTV (Serviço de Televisão da Comunidade Indígena) passou a usar um dos canais da Imparja para exibir conteúdos produzidos pela comunidades e falados em línguas Indígenas (MEADOWS, 2009). Em 2007, o NITV (Televisão Nacional Indígena) (Imagem 1) começou a ser transmitido e desde 2012 é operado pela SBS (Serviço Especial de Broadcasting). A criação da SBS desde a década de 1970 mudou a televisão Australiana e "forneceu um cronograma de programação alternativa para audiências marginais" (O'REGAN e KOLAR-PANOV 1993, p.121). Como consequência da programação multicultural da SBS, legendagem na televisão tornou-se comum para o público australiano.

Imagem 1: Logo da Televisão Nacional Indígena - NITV

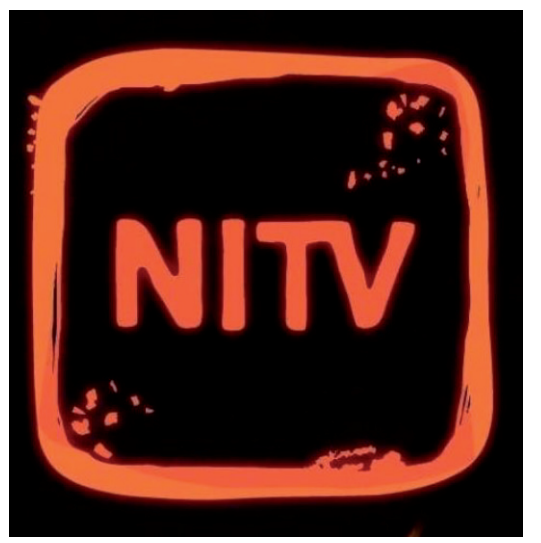

Fonte: http://www.50yearjourney.aiatsis.gov.au/stage7/_media/nitv_logo.jpg

Outra emissora pública também responsável pela exibição de conteúdo produzido pelos povos Indígenas foi a ABC (Corporação de Broadcasting Australiano). É uma emissora pública estatal que na década de 1980 também criou uma Unidade de Programas Aborígenes (APU), responsável pela produção de documentários e programas de televisão. As emissoras SBS e $A B C$ foram as primeiras plataformas tradicionais para artistas e produtores Indígenas desenvolverem "uma série de programas dentro do paradigma da televisão pública" (GINSBURG, 2010, 90). Desde então, através de produções audiovisuais, cineastas e produtores Aborígenes têm sido capazes de desenvolver uma voz muito importante, "que lhes permite criticar e analisar os efeitos históricos e em curso do colonialismo e, através da auto-representação, capacitar uma variedade de identidades Aborígenes contemporâneas, tanto tradicional como urbana" (BLACKMORE 2015, p.62). Neste sentido, é possível dizer que projetos de mídia Aborígenes estão fazendo exatamente o que Michael Leigh (1988, p.88) defendeu que eles poderiam fazer: "garantir a continuidade das suas línguas e culturas e representações" a partir dos seus próprios pontos de vista.

Se o conteúdo político das produções Indígenas pode ser identificado em discursos descolonizadores, quais são os paradigmas estéticos informado nessas produções? Ou seja, quais são as especificidades estéticas destes projetos? No livro "Bad Aboriginal Art" (1994), Eric Michaels dá um relato detalhado de como debates estéticos sobre obras de arte Aborígenes devem abordar as influências da cultura, dos valores, leis e conhecimentos dos povos Indígenas. Ao dizer isto, seu estudo da produção artística Warlpiri faz uma distinção entre gostos estéticos Aborígenes e europeus e os inevitáveis desafios em termos de avaliações e expectativas mútuas em um contexto transcultural. Consequentemente, as diferenças entre os códigos artísticos europeus e Aborígenes geram desafios para atividades comerciais como a compra e venda das artes Indígenas.

Michaels aponta que uma das principais dificuldades em estimar o preço da arte Aborígene relaciona-se com a importância dada pelos europeus à questão da autenticidade. Para o mercado europeu de arte, a autenticidade é uma definição chave da criatividade, originalidade e autoria das obras de arte. Por outro lado, esta medida dificilmente pode ser aplicada às obras de arte Aborígenes (especialmente as mais tradicionais, como pintura), já que elas são baseadas no conhecimento tradicional transmitido coletivamente através de gerações. Neste sentido, Michaels explica que, no caso da avaliação de obras de arte Aborígene, o termo-chave é a autoridade e não autenticidade. Autoridade diz respeito, essencialmente, aos direitos de representar e reproduzir a cultura, o conhecimento e os valores de um grupo em diferentes tipos de mídia. Portanto, a noção de autoridade coloca o artista não na posição individual de ser um único/criador original, mas como parte de um sistema coletivo de 
informações compartilhadas. Neste sentido, os artistas Aborígenes são responsáveis pela gestão da informação e, acima de tudo, de proteger significados e conhecimentos presente em obras de arte, da apropriação indevida por pessoas não autorizadas.

Embora reconhecendo esses dilemas transculturais na avaliação da arte, Michaels enfatiza que os artistas Aborígenes contemporâneos, conscientes das exigências europeias, estavam dispostos a negociar suas produções, a fim de trazer benefícios para suas comunidades. Como exemplo, ele cita a troca de "pinturas por Toyotas" (p. 54) pelos povos Warlpiri. Neste caso, designs tradicionais de pintura de areia foram adaptados nas portas de uma escola primária na comunidade Warlpiri e mais tarde reproduzidos e vendidos para fora da comunidade. $O$ dinheiro recebido da venda dos quadros foi suficiente para comprar duas Toyotas. Esta troca criou um círculo: de produzir obras de arte inspiradas por lugares em que os pintores estavam diretamente conectados à obtenção de carros para acessar e realizar rituais nesses locais sagrados que são geograficamente distantes. Neste sentido, o ato de vender as pinturas priorizou, acima de tudo, a manutenção das tradições Indígenas, em vez do reconhecimento autoral individualista recorrente na avaliação artística dos europeus.

No caso específico das produções audiovisuais, Michaels oferece um argumento convincente de como o background cultural Aborígene determina decisões estéticas, detalhando as filmagens do documentário "Coniston Story" (1984). Este vídeo retrata o massacre dos povos Warlpiri, depois da morte de um caçador branco por Aborígines no final de 1920. O vídeo foi baseado em testemunhos orais dos povos Aborígenes que, embora não sejam mostrados na frente das câmeras, autorizaram as filmagens dos locais históricos, bem como o registro sonoro de seus depoimentos sobre os fatos. O cineasta Francis Jupurrurla Kelly, membro da comunidade Warlpiri, filmou uma longa sequencia da paisagem vazia, como se a câmera estivesse seguindo as pessoas que andaram através destes espaços históricos e míticos. Como Michaels explica, o vídeo de Jupurrurla tenta retratar duas temporalidades paralelas: a primeira é a caminha- da dos antepassados e a segunda é a trilha dos policiais que executaram o massacre. Estes dois eventos temporais não lineares são apresentados simultaneamente através do movimento da câmera. Para o público em geral, estas imagens podem simplesmente aparecer como uma sequência muito lenta e chata de uma paisagem vazia. No entanto, para as pessoas da comunidade Warlpiri, a exibição desses sites geográficos através de um lento plano sequência que segue ambos, os antepassados e os policiais, são carregados com informações sensíveis e emotivas.

Este exemplo enfatiza o argumento de Michaels sobre a importância da inserção cultural, a fim de compreender as decisões estéticas e significados subjetivos das imagens. Nesse sentido, obras de arte devem ser vistas como parte de um processo e não como produtos finais. Esta mudança de perspectiva torna possível avaliar as opções estéticas que incluem as fases de produção e circulação, em vez de olhar para obras de arte como objetos estáticos. A conclusão de Michaels é que, na medida em que a cultura pode ser entendida como uma tradição que é comunicada de um para outro, o papel central dos meios de comunicação é a "manutenção ou a destruição cultural" (p.43). Por isso, ele acredita que as mídias Aborígenes podem, ao mesmo tempo apropriar a tecnologia para subverter a mídia comercial ou incorporar valores estéticos externos que são capazes de colocar a cultura Aborígene em alto risco.

No artigo "Embedded Aesthetics: Creating a Discursive Space for Indigenous Media", o antropólogo Faye Ginsburg (1994, p.368) afirma que os cineastas Indígenas e suas comunidades, através das suas produções audiovisuais, têm acesso a "espaços políticos, sociais, narrativos e imaginativos", que lhes permitam repensar a sua realidade presente e futura. Ao fazer isso, a mídia Indígena permite que eles renovem suas "práticas culturais locais", para inserirem "as suas histórias em imaginários nacionais" e criarem "novas arenas transnacionais" que liguem os povos Indígenas a um movimento coletivo que seja capaz de fazer "as suas preocupações visíveis para o mundo". Nessa tentativa que direciono minhas análises comparativas das produções Indígenas na Austrália e do Brasil, mostrando a possibilidade de comunicação assim como os desafios enfrentadas em cada um dos países. 
Na Austrália, a NITV, além de apresentar uma programação padrão semelhante a qualquer outro canal de televisão (que inclui noticiários, esportes, desenhos), tem também uma programação semanal em que a comunidade pode contar suas próprias histórias de maneiras diferentes. A lista inclui programas tais como: Surviving - apresentado às segundas-feiras, que gira em torno dos desafios contemporâneos da vida cotidiana de pessoas Aborígenes. "Desperate Measures" - exibido todas as terças-feiras, narra pela perspectiva Aborígene momentos históricos e movimentos políticos que mexeram com a história nacional. "Our Footprint" - às quartas-feiras, dá voz às pessoas idosas Aborígenes para que elas compartilhem as suas memórias e conhecimentos tradicionais. "Around the Campfire" - às quintas-feiras permite que as comunidades Aborígenes apresentem sua própria cidade e seus pontos turísticos. Aos sábados, "Unearthed" é um show de talentos para adolescentes Aborígenes, onde estes apresentam as suas competências desde seus talentos musicais até os desportivos. Finalmente, a cada segundo domingo, o programa "Ngurra" é centrado na apresentação da linguagem e conhecimento Aborígenes, ensinando aos jovens diversas habilidades desde a culinária tradicional até sobrevivência no mato. Além dos programas semanais, a NITV também produz séries de documentários em parceria com Screen Austrália (principal órgão público financiador do cinema australiano).

Semelhante à Austrália, os povos Indígenas no Brasil também estão lutando pela visibilidade de sua cultura e a descolonização da mídia tradicional. Embora estes dois países tenham diferentes histórias no desenvolvimento da mídia local, a década de 1980 foi chave para a representação colaborativa e a auto-representação Indígena. Isto é, quando o uso do vídeo analógico tornou-se amplamente disponível. É neste período que os canais de televisão Aborígene surgiram, bem como "programas de Aborígenes na televisão e organizações Indígenas que controlam serviços de televisão" (O'REGAN e BATTY 1993, p.174). Isto possibilitou aos povos Indígenas finalmente terem alguma influência sobre programas que envolvem conteúdo Aborígene. No caso do Brasil, a década de 1980 coincidiu com o fim da ditadura mi- litar e da censura explícita. Durante estes anos, antenas parabólicas e novas redes de televisão trouxeram uma diversidade de informações para a televisão brasileira (PRATA, 2002). Nos anos 1980, os movimentos Indígenas estavam começando a fazer manchetes apesar da mídia continuar exibindo imagens e discursos estereotipados sobre os povos Indígenas no Brasil. Diferente da história de desenvolvimento da mídia Australiana, que envolveu a criação de canais comunitários de televisão, no Brasil, a mídia Indígena se desenvolveu em espaços mais independentes e alternativos, tais como dentro das organizações não governamentais e sem fins lucrativos. Um dos exemplos mais antigos e bem sucedidos no Brasil é a criação do projeto Vídeo nas Aldeias.

\section{A Mídia Indígena no Brasil e o projeto VNA}

O Vídeo nas Aldeias é um projeto pioneiro na história da produção audiovisual Indígena no Brasil. O projeto foi originado pelo Centro de Advocacia Indígena (CAI) em 1987, tendo o antropólogo Vincent Carelli como principal fundador. Carelli vislumbrou na criação deste projeto a possibilidade de agregar povos Indígenas e dar visibilidade aos problemas persistentes de seus cotidianos, como o direito à terra, saúde e educação, além da necessidade de "encontrar meios de subsistência e integração na economia nacional" (CARELLI 2004, p. 22). O projeto inicial era filmar diferentes grupos Indígenas e compartilhar estas imagens entre eles, criando uma biblioteca audiovisual itinerante. $O$ projeto sempre teve como base a colaboração entre povos Indígenas e comunicadores não-Indígenas.

Imagem 2: Logo do projeto Vídeo nas Aldeias - VNA

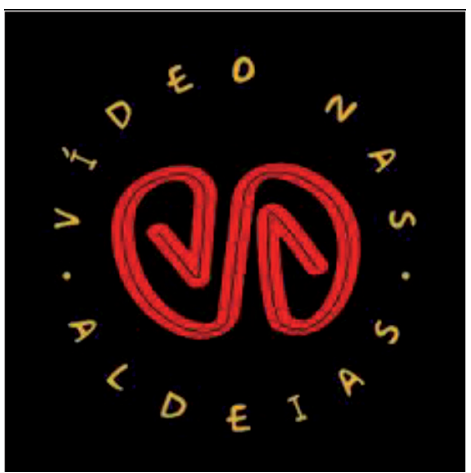

Fonte: https://vimeo.com/videonasaldeias 
Na primeira fase os comunicadores não-Indígenas foram responsáveis pela criação de todos os materiais audiovisuais. Na segunda fase, no entanto, o projeto desenvolveu a formação audiovisual dos povos Indígenas para que eles pudessem fazer seus próprios vídeos sob a supervisão dos técnicos e coordenadores do projeto. As fundações internacionais foram as primeiras patrocinadoras do projeto, a exemplo da Agência Norueguesa de Cooperação para o Desenvolvimento. Nesta época, alguns povos Indígenas já tinham contato com a televisão brasileira. Depois de lançar com sucesso alguns curtas em festivais internacionais, o projeto Vídeo nas Aldeias começou a produzir o"Programa de Índio" (a expressão é um trocadilho irônico pois é uma expressão comum empregada por não-Indígenas quando se referem a uma atividade desinteressante).

O Vídeo nas Aldeias, nesse sentido, tentou reutilizar essa expressão pejorativa e desafiar o público a criar novos significados para ela, assim como para suas opiniões preconcebidas sobre os povos Indígenas. A utilização desta expressão tentou reverter seu significado negativo, mostrando como "Programas de Índio" podem ser envolventes, divertidos e informativos. $O$ resultado foi bem recebido pelo público, apesar de não ter trazido inovações estéticas, já que seguia "um formato padrão de telejornal local" (AUFDERHEIDE 2008, p.30). O programa foi exibido em um canal regional público durante um ano (1995-1996). Embora sua exibição tenha durado apenas um curto período de tempo, o programa do Vídeo nas Aldeias teve considerável impacto e importância no desenvolvimento da mídia Indígena, abrindo espaço para uma nova fase de auto-representação na televisão brasileira.

Em 2000, a produtora de cinema Mari Corrêa ajudou a reestruturar o projeto Vídeo nas Aldeias como um todo; transformando-o em uma ONG cuja missão era ensinar cinema para os povos Indígenas no Brasil. A partir dai o Vídeo nas Aldeias produziu dez episódios do programa educacional "Índios do Brasil" para a TV ESCOLA (uma rede de televisão e radiodifusão pública educacional administrada pelo Ministério da Educação). Eles também produziram material didático para as escolas seguindo a lei federal no.11.645 (2008), que fez o ensino da cultura e história Indígena obrigatória no currículo escolar nacional, homologada durante o segundo mandato do presidente Lula da Silva (2002-2010). O Vídeo nas Aldeias também produziu uma série chamada "Olhares Indígenas" que foi exibida no " $A$ 'uwe", um programa de conteúdo exclusivamente Indígena apresentado pelo ator Marcos Palmeiras na TV Cultura. Os curtas também foram mostrados na TV Brasil, durante os anos de 2008 a 2011. Desde o fim do programa "A'uwe", não houve mais nenhum outro destinado especificamente a exibições de produções audiovisuais Indígenas na televisão brasileira. Consequentemente o acervo do Vídeo nas Aldeias agora tem como principal veículo de exibição os canais da Internet e os seus próprios DVDs.

Os conteúdos da produção audiovisual do Vídeo nas Aldeias podem ser divididos em duas temáticas principais: O registro de práticas tradicionais da vida cotidiana e as lutas Indígenas por direitos básicos. No caso da primeira temática, o foco é em filmar manifestações culturais Indígenas com a intenção de registro e preservação da memória para as gerações mais jovens. A segunda temática tem gerado vídeos dedicados ao registro das lutas pelo direito à terra e as tentativas de proteger territórios tradicionais da invasão ilegal, além de outras reivindicações, como encontrar formas econômicas de sobrevivência no mercado capitalista contemporâneo brasileiro.

O Vídeo nas Aldeias provavelmente é o projeto de audiovisual Indígena mais famoso no Brasil, mas não é o único. Vários projetos recentes envolvem parcerias entre os povos Indígenas e cineastas não-Indígenas que trabalham na formação de comunicadores, capacitando-os (as) para trabalharem na produção, circulação e distribuição de produtos audiovisuais Indígenas no Brasil. As novas tecnologias têm sido fundamentais para esse desenvolvimento. Este é o caso do projeto, "Vidas Paralelas", que faz seus vídeos nas câmeras dos aparelhos celulares. ${ }^{2} \mathrm{O}$ projeto foi criado em 2010, como parte da demanda de estudantes Indígenas na Universidade de Brasília, que desejam manter suas conexões com suas comunidades/ nações de origem. $O$ projeto envolve muitas nações diferentes, tais como os Pataxó, Kariri-Xocó, Potiguara, Tupinikim, entre outros. Os estudantes da universidade convidam membros de suas comunidades para partici- 
parem de oficinas de fotografia e audiovisual, dispostos a promoverem e apresentarem a vida contemporânea dos povos Indígenas.

Outro projeto similar em andamento é do Instituto Catitu, que também ensina aos povos Indígenas a produzirem seus filmes. Um diferencial deste projeto é o foco especifico na capacitação e formação de mulheres Indígenas para que atuem como comunicadoras. $\mathrm{O}$ instituto foi criado em 2009 pela ex-integrante do Vídeo nas Aldeias, Mari Côrrea. ${ }^{3}$ À medida que crescem o número de projetos e de produções Indígenas também aumenta a diversidade de formatos, discursos e estéticas. Se a maioria desses projetos primeiramente visaram a formação técnica de comunicadores Indígenas, agora começam os projetos de circulação desse material audiovisual como é o caso do festival Cine Kurumim que tem exibido filmes Indígenas ao redor do Brasil. ${ }^{4}$ Outro desdobramento interessante desses projetos é o inicio do desenvolvimento da carreira de cineastas/comunicadores Indígenas. Nomes como o de Takuma Kuikuro tornaram-se recentemente famosos a partir da circulação em festivais nacionais e internacionais do docudrama Hipermulheres (2012), dirigido por ele em parceria dos cineastas não-Indígenas Carlos Fausto e Leonardo Sette e produzido pelo projeto Vídeo nas Aldeias. ${ }^{5}$

\section{Algumas convergências/divergências entre NITV e VNA}

Uma principal convergência entre ambos os projetos de mídia Indígenas, NITV e VNA, é o fato das produções audiovisuais dos dois serem feitas em primeiro lugar para os próprios povos Indígenas e em segundo lugar para o público geral. Neste sentido, eles operam em sincronia com a noção de Eric Michaels de apropriação de tecnologias estrangeiras/exteriores à própria cultura, para o fortalecimento das estéticas Indígenas/tradicionais e não para a reprodução de uma estética e conteúdo comercial. Em ambos os projetos o conteúdo político e estético é voltado para a valorização da cultura e da língua local. Ao invés de tentar agradar primeiramente um público mais vasto, esses projetos visam atender aos objetivos das comunidades retratadas, divulgando seus modos de vida, seus problemas cotidianos e operando na construção de novas narrativas em que os atores/entrevistados Indígenas ocupam o papel principal.

Outra semelhança na produção desses dois projetos coletivos é o fato da maioria dos documentários/programas serem produzidos em um formato convencional de narração em voz over e entrevistas. Apesar desse formato não trazer novidades, o diferencial dessas produções é que os povos Indígenas assumem um papel novo nessas narrativas, o de especialistas. Ao invés de serem exibidos como objetos etnográficos, eles finalmente assumem o papel de sujeitos e narradores de suas próprias histórias, lugares de origem, tradições e modos de vida. Ao mostrarem seus conhecimentos a respeito dos lugares filmados, os comunicadores Indígenas efetivam o argumento de Michelle Raheja, a respeito da conexão geográfica e temporal dos comunicadores Indígenas com os temas de suas produções.

É verdade que nestas produções geralmente não há espaço para vozes dissonantes que questionem as perspectivas dos povos Indígenas. No entanto, essas produções oferecem uma oportunidade prodigiosa de ouvir vozes alternativas que raramente são escutadas na grande mídia. Neste sentido, a mídia Indígena é um tipo de "mídia alternativa", pois permite "vozes marginais e de oposição contestarem a visão de mundo, valores e estilos de vida do mainstream" e ao fazerem isso, estimulam a "circulação e crescimento de subculturas e comunidades alternativas" (KELLNER 1989, 144). O desenvolvimento dos meios de comunicação Indígenas é fundamental para que estas perspectivas sejam amplamente vistas e ouvidas.

As produções de ambos os projetos são definitivamente feitas para serem mais do que educativas ou de entretenimento. Os dois projetos, NITV and VNA, não apenas registram importantes conhecimentos sobre as práticas culturais Indígenas como eles também assumem um papel político na recuperação e conservação de cada cultura. Ao assumir esse papel os dois projetos contribuem para a revitalização das culturas Indígenas, de acordo com sua declaração internacional: os povos Indígenas 
têm o direito a revitalizar, utilizar, desenvolver e transmitir às gerações futuras suas histórias, línguas, tradições orais, filosofias, sistemas e literaturas escrita, e para designar e reter seus próprios nomes para comunidades, lugares e pessoas (Declaração dos Direitos dos povos Indígenas, o artigo 13, 2007).

Apesar desses dois projetos terem uma atuação convergente no que diz respeito ao processo de descolonização midiática de cada país, eles também apresentam uma serie de diferenças em sua estrutura. O projeto Vídeo nas Aldeias é uma organização não governamental, sem fins lucrativos, que para continuar produzindo depende de editais públicos e privados assim como de fundos de financiamento internacionais. Por outro lado a NITV é um canal aberto de televisão (34), financiado pelo estado Australiano e acessível para a maioria da população (95\%). A produção do canal é diária e o grupo de técnicos e produtores envolvidos prioriza o slogan de "um canal que é feito por, para e sobre os Aborígenes". ${ }^{6} \mathrm{O}$ conteúdo do canal é também disponibilizado gratuitamente no canal online da "SBS on demand", o que significa que o público australiano pode assistir novamente a programação do NITV pela Internet no horário em que desejar.

No entanto, a maior diferença entre os dois projetos NITV e VNA é o fato de que na Austrália as produções audiovisuais Indígenas são primeiramente baseadas na auto-representação, já que são realizadas em grande parte por diretores e produtores Indígenas. A lista inclui longas e curtas metragens de ficção, assim como documentários e programas de televisão, dirigidos, produzidos ou atuados por Aborígenes. ${ }^{7}$ Em comparação ao Brasil, que por exemplo ainda não tem nenhum longa de ficção dirigido por um comunicador Indígena, a lista australiana impressiona. No entanto, a produção Aborígene apresenta um crescimento enorme a partir dos anos 2000, demostrando uma tendência mundial de desenvolvimento da mídia Indígena nas últimos anos. No Brasil, as produções Indígenas ainda são em grande parte baseadas na "construção representativa" (ALIA and BULL 2005, p.76) em que Indígenas e não-Indígenas trabalham em um processo de negociação e cooperação para realizarem uma produção conjunta.
Apesar da diferença de recursos entre os projetos e do volume de produções Indígenas em casa país, é possível achar uma principal convergência entre o NITV e o VNA: ambos proporcionam formas alternativas de manutenção cultural com o registro de tradições orais, músicas, danças, performances e pinturas. Ao fazerem isso, eles também reforçam o papel dos meios de comunicação como uma forma de expressão cultural como parte da luta Indígena por acessibilidade à produção e distribuição de materiais audiovisuais que podem promover a compreensão intercultural. Por outro lado, essas produções também proporcionam a disseminação de imagens e discursos contemporâneos fundamentais para desmistificar estereótipos e atualizar as identidades dos povos Indígenas nesses dois países.

\section{Considerações finais}

Na Austrália e no Brasil, os povos Indígenas se tornaram minorias enquanto lutavam contra os efeitos da colonização externa e interna. Essa luta que já dura alguns séculos ainda persiste nos dois países, e em ambos, os povos Indígenas batalham para preservar suas próprias culturas, línguas e modos de vida. Neste contexto, a apropriação das novas tecnologias midiáticas tem sido uma ferramenta fundamental para o processo de resistência cultural e descolonização. Neste artigo eu demostrei que algumas formas de produções audiovisuais Indígenas foram usadas para fortalecer as agendas políticas e culturais dos povos Indígenas.

As produções audiovisuais coletivas, como o canal de televisão NITV e o projeto Vídeo nas Aldeias estão sendo capazes de trazer narrativas Indígenas com suas próprias vozes e imagens não apenas para o âmbito local, mas também para o público global. $O$ aumento da auto-representação Indígena nas produções audiovisuais se tornou possível tanto pela acessibilidade aos meios de produção das novas mídias quanto pelo fortalecimento dos movimentos Indígenas. Nesse sentido, o desenvolvimento do cinema e da televisão Indígena estão progressivamente trazendo mudanças políticas e estéticas para esses meios de comunicação. Assim como na Austrália, também no Brasil, a mídia Indígena tem sido produzida 
localmente e distribuída em vários níveis, desde dentro de sua própria comunidade, bem como a nível nacional e mesmo internacional, através de festivais de cinema ou canais on-line.

Apesar das diferenças históricas, o desenvolvimento dos meios de comunicação Indígenas na Austrália e Brasil compartilham desafios comuns, mas também realizações incontestáveis. Apesar de apresentarem histórias nacionais e experiências coloniais especificas, as lutas Indígenas nos dois países envolveram violência, resistência, negociação e apropriação das tecnologias ocidentais, tais como o cinema e a televisão. A continua produção de material audiovisual feita pelo Vídeo nas Aldeias e pelo NITV são exemplos irrefragáveis de realizações que permitem trazer perspectivas Indígenas para um debate nacional e até transacional.

\section{Referências}

BARCLAY, Barry. Celebrating Fourth Cinema. Illusions. n35, Winter, pp 7-11, 2003.

CARELLI, Vicent. Eu, um Índio. In: Catálogo da 'Mostra vídeo nas Aldeias: um olhar indígena' Rio de Janeiro: Vídeo nas Aldeias. Abril, pp 20-25, 2004.

ELSAESSER, Thomas. European Cinema: Face to Face with Hollywood. Amsterdam University Press, Amsterdam 2005.

GAUNSON, Stephen. Re-reading Indigenous cinema: criticism, white liberal guilt and otherness. Continuum: Journal of Media \& Cultural Studies, ano 27, n.6, pp.763-769, 2013.

GINSBURG, Faye. Peripheral Visions: Blak Screens and Cultural Citizenship. IORDANOVA, Dina, David Martin-Jones, and Belén Vidal. Cinema at the Periphery. Detroit: Wayne State University Press, 2010

GINSBURG, Faye. Embedded Aesthetics: Creating a Discursive Space for Indigenous Media. Cultural Anthropology Ano 9, n.3, pp 365-82. 1994.

GINSBURG, Faye Indigenous Media: Faustian Contract or Global Village? Cultural Anthropology, ano 6, n.1, pp.92-112, 1991

HIGSON, Andrew. The concept of national cinema. Screen, ano 30, n.4 pp 36-47, 1989.

JACKA, Elizabeth. The Australian Media Landscape: Recent Changes. Canadian Journal of Communication ano 17 n. 4, 1992.
LEIGH, Michael Curiouser and Curiouser, in MURRAY, Scott (Org.) Back of Beyond: Discovering Australian Film and Television, pp.70-89, Sydney: Australian Film Commission 1988.

MEADOWS, Michael. Electronic Dreaming Tracks: Indigenous Community Broadcasting in Australia. Development in Practice ano.19, n.4 pp.514-24, 2009

MEADOWS, Michael and MOLNAR, Helen Bridging the Gaps: Towards a history of Indigenous media in Australia, Media History, ano 8, n.1, pp.9-20, 2002

MICHAELS, Eric. Bad Aboriginal Art: Tradition, Media, and Technological Horizons, Minneapolis: University of Minnesota Press, 1994.

O'REGAN, Tom. Australia national cinema. London: Routledge, 1996.

O'REGAN, Tom and Dona Kolar-Panov. SBS-TV: Symbolic politics and multicultural policy in television provision in O'REGAN, Tom Australian Television Culture, Australian Cultural Studies Series. Sydney: Allen \& Unwin, 1993, pp.121-142.

O'REGAN, Tom and Philip Batty. An Aboriginal television culture: Issues, strategies, politics in O'REGAN, Tom Australian Television Culture: Australian Cultural Studies Series. Sydney: Allen \& Unwin, 1993, pp.169-192.

PRATA, Monica Nadler. The Representation of the Brazilian Indian in Literature and Cinema from Hans Staden to the Indigenous Media. ProQuest Dissertations Publishing, 2002.

RAHEJA, Michelle H. Reservation Reelism: Redfacing, Visual Sovereignty, and Representations of Native Americans in Film. Lincoln: University of Nebraska Press, 2011; 2010.

RENNIE, Ellie, and FEATHERSTONE, Daniel. The Potential Diversity of Things we Call TV': Indigenous Community Television, Self-Determination and NITV. Media International Australia, Incorporating Culture \& Policy, n.129,pp.52-66, 2008.

SPURGEON, Christina. Challenging technological determinism: Aborigines, Aussat and remote Australia. WILSON, Helen (Org.), Australian communications and the public sphere, pp. 27-45. Melbourne: Macmillan, 1989.

WOOD, Houston. Native Features: Indigenous Films from Around the World. New York: Continuum, 2008.

\section{Notas}

1 Na Austrália, em 1898, o antropologista inglês Alfred Haddon, filmou em $35 \mathrm{~mm}$ os primeiros registros etnográficos de povos Indígenas que se tem conhecimento. Entre as filmagens de Haddon, apenas quatro minutos de imagens em movimento de homens dançando e fazendo fogo sobreviveram (FitzSimons, Laughren, e Williamson, 2011). No Brasil, as primeiras imagens etnográficas dos povos Indígenas foram 
realizadas por Edgar Roquette-Pinto. Suas filmagens registraram tarefas diárias do cotidiano dos povos Nhambiquaras como a preparação da mandioca, fiação e tecelagem (Pinto 1938). Em ambos os casos, as imagens registradas colocavam os povos Indígenas como objetos de curiosidade para investigações antropológicas.

2 Página oficial: http://www.projetovidasparalelas.com.br/

3 Página oficial: http://institutocatitu.org.br/

4 Página oficial: https://cinekurumin.com

$5 \mathrm{O}$ docdrama recebeu o prêmio de documentário da Al Jazeera em Vancouver Film Festival Latino-Americana (2012) e ganhou como o melhor documentário no 4oth Festival Hollywood Brazilian Film (2012).

6 Página oficial: http://www.sbs.com.au/nitv/

7 Lista completa da produções audiovisual Aborígene entre as décadas de 1970s-2010s: http://www.screenaustralia.gov.au/fact-finders/ production-trends/indigenous-production

Recebido em 30 de outubro de 2016

Aceito em 29 de janeiro de 2017. 
